\title{
CORRECTION
}

View Article Online

View Journal I View Issue

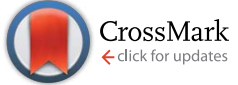

Cite this: RSC Adv., 2016, 6, 83710

DOI: 10.1039/c6ra90083f

www.rsc.org/advances

\section{Correction: pHLIP-modified magnetic nanoparticles for targeting acidic diseased tissue}

A. M. Demin, ${ }^{a}$ A. G. Pershina, ${ }^{\star b c}$ K. V. Nevskaya, ${ }^{b}$ L. V. Efimova, ${ }^{b}$ N. N. Shchegoleva, ${ }^{d}$ M. A. Uimin, ' D. K. Kuznetsov, ${ }^{\text {e }}$ V. Ya. Shur, ${ }^{\text {e V. P. Krasnov and L. M. Ogorodova }}{ }^{\text {b }}$

Correction for 'pHLIP-modified magnetic nanoparticles for targeting acidic diseased tissue' by A. M. Demin et al., RSC Adv., 2016, 6, 60196-60199.

The authors regret that Scheme 1 in the original article requires correction. The structure of EMCS in the original article omits one of its two nitrogen atoms. The correct structure of EMCS is depicted in the amended scheme shown herein.

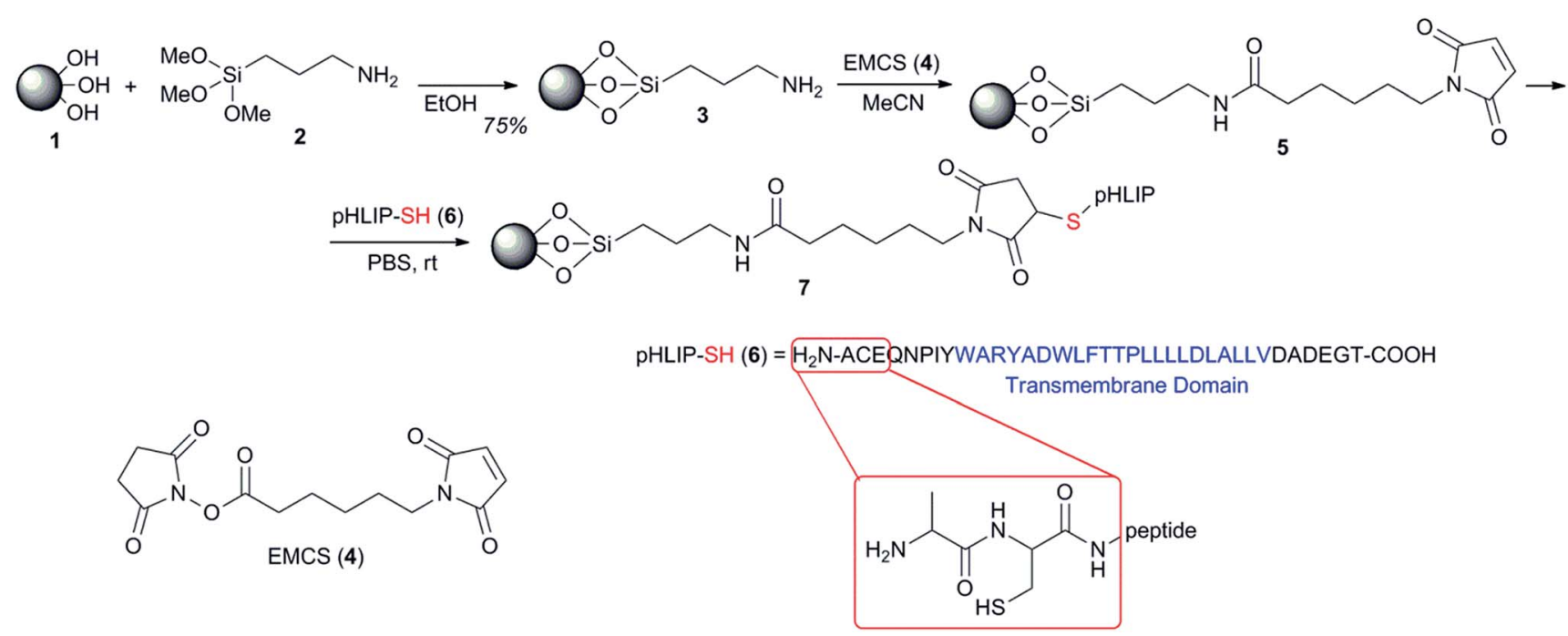

Scheme 1 Immobilization of pHLIP on MNPs.

The Royal Society of Chemistry apologises for these errors and any consequent inconvenience to authors and readers. 